\title{
Pyloricidins ${ }^{\dagger}$, Novel Anti-Helicobacter pylori Antibiotics Produced by Bacillus sp.
}

\section{Isolation and Structure Elucidation}

\author{
Yoichi Nagano, Kojl Ikedo, Akira Fujishima a, Motowo IzaWa, Shigetoshi Tsubotani*, \\ OSAMU NishimURA ${ }^{b}$ and MASAHIKo FuJINo ${ }^{c}$ \\ Pharmaceutical Discovery Center, Pharmaceutical Research Division, Takeda Chemical Industries, Ltd., \\ 2-17-85, Juso-Honmachi, Yodogawa-ku, Osaka 532-8686, Japan \\ ${ }^{a}$ Medicinal Chemistry Research Laboratories I, Pharmaceutical Research Division, Takeda Chemical Industries, Ltd., \\ 2-17-85, Juso-Honmachi, Yodogawa-ku, Osaka 532-8686, Japan \\ ${ }^{\mathrm{b}}$ Pharmaceutical Research Division, Takeda Chemical Industries, Ltd., \\ Wadai 10, Tsukuba, Ibaraki 300-4293, Japan \\ ${ }^{\mathrm{c}}$ Takeda Chemical Industries, Ltd. \\ 4-1-1, Doshomachi, Chuo-ku, Osaka 540-8645, Japan
}

(Received for publication May 28, 2001)

\begin{abstract}
Novel anti-Helicobacter pylori antibiotics, pyloricidins $\mathrm{A}, \mathrm{A}_{1}, \mathrm{~A}_{2}, \mathrm{~B}, \mathrm{C}$ and $\mathrm{D}$ were isolated from Bacillus sp. HC-70 and Bacillus sp. HC-72 by column chromatographies using adsorption and ion exchange resins. Their structures have been elucidated based on spectroscopic and degradation studies and shown to be peptide-like compounds. These compounds contained two unusual amino acids, viz., 5-amino-2,3,4,6-tetrahydroxyhexanoic acid and 3-amino-3-phenylpropionic acid ( $\beta$-phenylalanine). The structure-activity relationship studies suggested that 3-(5-amino-2,3,4,6-tetrahydroxyhexanoyl)amino-3-phenylpropionic acid moiety was essential for anti-H. pylori activity,
\end{abstract}

Peptic ulcer disease affects many people in the world. Although the disease has relatively low mortality, it is still a major health problem. In the past, this disease was believed to be related to stress and excess of the digestive secretions such as gastric acid. In 1983, WARRen and Marshall isolated a spiral Gram-negative bacterium Helicobacter pylori, from patients with gastric ulcer disease ${ }^{1)}$. Recent studies revealed that $H$. pylori was strongly associated with peptic ulcer disease and eradication of $H$. pylori could cure and reduce its recurrence ${ }^{2}$. Various therapeutic regimens have been used in the treatment of peptic ulcer, but antibiotics alone could not achieve $H$. pylori eradication. Thus, triple therapy consisting of a proton pump inhibitor and antibiotics, such as amoxicillin and clarithromycin, is recommended now ${ }^{3,4}$. This therapy has yielded eradication rates of greater than $80 \%$. However, side effects have been recorded in a significant number of patients and antibiotic resistance has also been shown to be prevalent ${ }^{5}$. Therefore, drugs which have strong anti-H. pylori activity and no significant side effects were required.

In a screening program designed to discover new antiHelicobacter pylori antibiotics from microorganisms, pyloricidins A (1), $A_{1}(\mathbf{1 a}), A_{2}(\mathbf{1 b}), B(2)$ and $C(3)$ were isolated from Bacillus sp. HC-70, and pyloricidins C (3) and D (4) from Bacillus sp. HC-72 (Fig. 1). These compounds had specific activity against $H$. pylori. The taxonomy of the producing strain, fermentation and biological activity of pyloricidins were reported in another paper $^{6)}$.

In this paper, we report the isolation and structural elucidation of pyloricidins.

\footnotetext{
* Corresponding author: Tsubotani_Shigetoshi@takeda.co.jp

Pyloricidins were presented as HC-70s in WO99/2549 (January 21, 1999).
} 
Fig. 1. Structures of pyloricidins.<smiles>[R]NC(CO)[C@@H](O)[C@H](O)[C@H](O)C(=O)N[C@H](CC(=O)O)c1ccccc1</smiles>

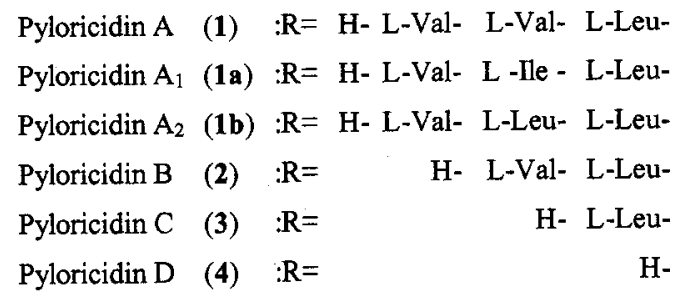

\section{Results}

Isolation

A preliminary test showed that anti-H. pylori activity was found in the culture filtrate rather than in the cell mass. As pyloricidins were amphoteric, water-soluble substances, they were purified by column chromatographies using cation exchange resins such as Amberlite IR-120 and Lewatit CNP-80, anion exchange resin such as Amberlite IRA-67, and adsorption resins such as Diaion HP-20, Sepabeads SP-207 and Sepabeads SP-850.

Since the production ratio of pyloricidins varied with the fermentation time ${ }^{6)}$, pyloricidins $A(\mathbf{1}), A_{1}(\mathbf{1 a})$ and $A_{2}(\mathbf{1 b})$ were isolated from the fermentation broth of Bacillus sp. HC-70 cultured for 30 hours, and pyloricidins B (2) and C (3) from the broth of the same strain cultured for 42 hours. The isolation procedure of $\mathbf{2}$ and $\mathbf{3}$ is outlined in Fig. 2. Separation of $\mathbf{2}$ and $\mathbf{3}$ was performed by SP-850 chromatography. Compound $\mathbf{1}$ was isolated according to a similar method to $\mathbf{2}$ and $\mathbf{3}$. Compounds $\mathbf{1 a}$ and $\mathbf{1 b}$ were isolated as minor products from crude crystals of $\mathbf{1}$ using preparative HPLC.

In addition, pyloricidins $C(3)$ and D (4) were isolated from the broth filtrate of Bacillus sp. HC-72 and separation of 3 and $\mathbf{4}$ was carried out by SP-207 chromatography. The fractions containing pyloricidins were detected by the antibacterial activity against $H$. pylori and HPLC analysis during the purification process. Details of the isolation procedures of pyloricidins are described in the experimental section.

\section{Physico-chemical Properties}

The physico-chemical properties of pyloricidins are summarized in Table 1. These compounds are soluble in water, DMF, DMSO and pyridine but insoluble in EtOAc and $n$-hexane. They showed positive color reactions with ninhydrin and Greig-Leaback reagents and negative color reactions with Ehrlich and Sakaguchi reagents.

The presence of amide groups was suggested by the characteristic absorption at $1630 \sim 1660 \mathrm{~cm}^{-1}$ in the IR spectrum. In addition, characteristic $\mathrm{NH}$ signals at $7 \sim 9 \mathrm{ppm}$ in the ${ }^{1} \mathrm{H}$ NMR spectra and signals of carbonyl and their $\alpha$-carbon in the ${ }^{13} \mathrm{C}$ NMR spectra indicated that 1 $\sim 4$ were peptide-like compounds. The results of amino acid analysis of the compounds upon acid hydrolysis are shown in Table 1.

\section{Structure Elucidation}

Structure of 3

The molecular formula of $\mathbf{3}$ was determined to be $\mathrm{C}_{21} \mathrm{H}_{33} \mathrm{~N}_{3} \mathrm{O}_{8}$ by molecular ion measurement in the FAB-MS, ${ }^{13} \mathrm{C}$ NMR spectra and elemental analysis. The molecular formula indicated seven degrees of unsaturation. The amino acid constitution of 3 was Leu ( $1 \mathrm{~mol})$ and $\beta$-phenylalamine ( $\beta$-Phe, $1 \mathrm{~mol}$ ) by amino acid analysis. The structure of $\mathbf{3}$ was elucidated from analysis of ${ }^{1} \mathrm{H}$ and ${ }^{13} \mathrm{C}$ NMR (Table 22) and 2D NMR experiments such as ${ }^{1} \mathrm{H}-{ }^{1} \mathrm{H}$ COSY, ${ }^{1} \mathrm{H}-{ }^{13} \mathrm{C}$ COSY and HMBC. Twenty-one carbons in the ${ }^{13} \mathrm{C}$ NMR spectra were assigned to two methyl, three methylene, seven methine, five olefinic methine, one olefinic quarternary and three carbonyl carbons by DEPT experiments including overlapping signals at $\delta 126.46$. Among them, fifteen carbon signals were easily assigned to the signals due to Leu and $\beta$-Phe moieties. The remaining six carbon signals were deduced to be one aminomethine $(\delta$ 51.22 ), one oxymethylene ( $\delta 60.92)$, three oxymethine ( $\delta$ $67.63,70.74$ and 71.21$)$ and one carbonyl ( $\delta$ 172.39) carbons. Considering the degrees of unsaturation, no additional ring system exists in this six-carbon moiety. All of these data suggested that these six carbons formed a new tetrahydroxyamino acid moiety. The ${ }^{1} \mathrm{H}-{ }^{1} \mathrm{H}$ COSY data revealed the coupling between $2-\mathrm{H}(\delta 4.13)$ and $3-\mathrm{H}(\delta$ $3.52)$; $3-\mathrm{H}$ and $4-\mathrm{H}(\delta 3.77) ; 5-\mathrm{H}(\delta 3.99)$ and $\mathrm{NH}(\delta 7.85)$; $5-\mathrm{H}$ and 6-H ( $\delta$ 3.43) (Fig. 3). This showed the partial structures, $-\mathrm{CH}(-\mathrm{O}-)-\mathrm{CH}(-\mathrm{O}-)-\mathrm{CH}(-\mathrm{O}-)-$ (i) and $-\mathrm{CH}(-\mathrm{NH}-)-\mathrm{CH}_{2} \mathrm{O}-(\mathrm{ii})$. In addition; the $\mathrm{HMBC}$ spectrum 
Table 1. Physico-chemical properties of pyloricidins $(\mathbf{1} \sim \mathbf{4})$.

\begin{tabular}{|c|c|c|c|c|c|}
\hline & Pyloricidin A (1) & Pyloricidin & $\mathrm{B}(2)$ & Pyloricidin C (3) & Pyloricidin D (4) \\
\hline Appearance & Colorless needles & Colorless $n$ & eedles & Colorless needles & Colorless needles \\
\hline$[\alpha]_{D}^{24}$ & $-89^{\circ}(\mathrm{c} 0.53,0.1 \mathrm{~N} \mathrm{HCl})$ & $-69^{\circ}$ (c 0.5 & $0,0.1 \mathrm{~N} \mathrm{HCl})$ & $-67^{\circ}(\mathrm{c} 0.55,0.1 \mathrm{~N} \mathrm{HCl})$ & $-89^{\circ}(\mathrm{c} 0.53,0.1 \mathrm{~N} \mathrm{HCl})$ \\
\hline $\mathrm{UV} \lambda_{\max }\left(\mathrm{H}_{2} \mathrm{O}\right) \mathrm{nm}(\varepsilon)$ & $258(310)$ & $257(270)$ & & $257(350)$ & $257(310)$ \\
\hline $\mathbb{I R} v_{\max }(\mathrm{KBr}) \mathrm{cm}^{-1}$ & $\begin{array}{l}3300,2960,1640,1540, \\
1400,1050\end{array}$ & $\begin{array}{l}3370,2970 \\
1400,1050\end{array}$ & 1630,1520 & $\begin{array}{l}3390,2970,1660,1540 \\
1400,1050\end{array}$ & $\begin{array}{l}3370,2940,1650,1540 \\
1400,1050\end{array}$ \\
\hline \multicolumn{6}{|l|}{ Elemental analysis } \\
\hline Found & $\begin{array}{l}\text { C } 55.23 \\
\text { H } 8.03 \\
\text { N } 10.47\end{array}$ & $\begin{array}{l}\text { C } 51.44 \\
\text { H } 7.84 \\
\text { N } 9.32\end{array}$ & & $\begin{array}{l}\text { C } 53.14 \\
\text { H } 7.14 \\
\text { N } 8.98\end{array}$ & $\begin{array}{l}\text { C } 49.11 \\
\text { H } 6.78 \\
\text { N } 7.89\end{array}$ \\
\hline Calcd & $\begin{array}{l}\text { C } 55.43 \\
\text { H } 7.95 \\
\text { N } 10.42\end{array}$ & $\begin{array}{l}\text { C } 51.30 \\
H 7.95 \\
\text { N } 9.20\end{array}$ & & $\begin{array}{l}\text { C } 53.27 \\
\text { H } 7.45 \\
\text { N } 8.87\end{array}$ & $\begin{array}{l}\text { C } 48.78 \\
\text { H } 6.82 \\
\text { N } 7.58\end{array}$ \\
\hline Molecular formula & $\mathrm{C}_{31} \mathrm{H}_{51} \mathrm{~N}_{5} \mathrm{O}_{10}\left(\mathrm{H}_{2} \mathrm{O}\right)$ & $\mathrm{C}_{26} \mathrm{H}_{42} \mathrm{~N}_{4} \mathrm{O}$ & $\left(3 \mathrm{H}_{2} \mathrm{O}\right)$ & $\mathrm{C}_{21} \mathrm{H}_{33} \mathrm{~N}_{3} \mathrm{O}_{8}\left(\mathrm{H}_{2} \mathrm{O}\right)$ & $\mathrm{C}_{15} \mathrm{H}_{22} \mathrm{~N}_{2} \mathrm{O}_{7}\left(1.5 \mathrm{H}_{2} \mathrm{O}\right)$ \\
\hline FAB-MS $(\mathrm{m} / \mathrm{z})$ & $654(\mathrm{M}+\mathrm{H})^{+}$ & $555(\mathrm{M}+\mathrm{H})$ & & $456(\mathrm{M}+\mathrm{H})^{+}$ & $342(\mathrm{M}+\mathrm{H})^{+}$ \\
\hline Amino acid analysis ${ }^{\circ !}$ & $\begin{array}{ll}\text { L-Val } & (2 \mathrm{~mol}) \\
\text { L-Leu } & (1 \mathrm{~mol}) \\
\beta-P h e & (1 \mathrm{~mol})\end{array}$ & $\begin{array}{l}\text { L-Val } \\
\text { L-Leu } \\
\beta \text {-Phe }\end{array}$ & $\begin{array}{l}(1 \mathrm{~mol}) \\
(1 \mathrm{~mol}) \\
(1 \mathrm{~mol})\end{array}$ & $\begin{array}{ll}\text { L-Leu } & (1 \mathrm{~mol}) \\
\beta-P h e & (1 \mathrm{~mol})\end{array}$ & $(1 \mathrm{~mol})$ \\
\hline Edman degradation & $\mathrm{Val} \rightarrow \mathrm{Val} \rightarrow \mathrm{Leu}$ & $\mathrm{Val} \rightarrow \mathrm{Leu}$ & & & \\
\hline Rf.(Silica gel TLC) ${ }^{* 2}$ & 0.45 & 0.41 & & 0.35 & 0.30 \\
\hline Rt. (minutes) ${ }^{\cdot 3}$ & 16.8 & 8.1 & & 6.0 & 4.0 \\
\hline
\end{tabular}

\footnotetext{
${ }^{11} 6 \mathrm{~N} \mathrm{HCl}, 110^{\circ} \mathrm{C}, 24 \sim 72$ hours

${ }^{* 2}$ Merck Kieselgel $60 \mathrm{~F}_{254}$ : n-BuOH-AcOH- $\mathrm{H}_{2} \mathrm{O}$ (12:3:5)

${ }^{*}$ Solvent system: $\mathrm{CH}_{3} \mathrm{CN}-20 \mathrm{mM} \mathrm{KH}{ }_{2} \mathrm{PO}_{4}$ 15:85 (v/v), $1.0 \mathrm{ml} / \mathrm{min}$

Column YMC-Pack ODS-A, A-312 $\$ 6.0 \mathrm{~mm} \times 150 \mathrm{~mm}$
}

indicated the following two- and three-bonds connectivities; from $2-\mathrm{H}$ to carbonyl carbon $\mathrm{C}-1(\delta 172.39), \mathrm{C}-3(\delta 71.21)$ and $\mathrm{C}-4(\delta 67.63)$, from $3-\mathrm{H}$ to $\mathrm{C}-1, \mathrm{C}-2(\delta 70.74)$ and $\mathrm{C}-5$ $(\delta 51.22)$, from $4-\mathrm{H}$ to $\mathrm{C}-6(\delta 60.92)$, from $5-\mathrm{H}$ to $\mathrm{C}-6$, and from $6-\mathrm{H}$ to $\mathrm{C}-4$ and $\mathrm{C}-5$. This result combined the partial structures (i) and (ii), and clarified the unidentified tetrahydroxyamino acid to be 5-amino-2,3,4,6-tetrahydroxyhexanoic acid (5-ATHH).

The sequence of these amino acids was revealed by HMBC experiment. As shown in Fig. 3, the amide protons of 5-ATHH ( $\delta 7.85)$ and $\beta$-Phe $(\delta 8.34)$ gave cross peaks with carbonyl carbons of leucine $(\delta$ 174.27) and 5-ATHH ( $\delta$ 172.39), respectively. Finally, the structure of 3 was determined to be 3-(5-leucylamino-2,3,4,6-tetrahydroxyhexanoyl)amino-3-phenylpropionic acid.

\section{Structures of $\mathbf{1}, \mathbf{1 a}, \mathbf{1 b}, \mathbf{2}$ and $\mathbf{4}$}

The NMR data (Table 2) indicated that $\mathbf{1}$ and $\mathbf{2}$ also contained Leu, 5-ATHH and $\beta$-Phe moieties as 3. Furthermore, $\mathbf{1}$ and $\mathbf{2}$ yielded $\mathbf{3}$ by enzymatic conversion using leucine aminopeptidase. This result suggested that $\mathbf{1}$ and 2 had peptide or amino acid binding to $N$-terminus of 3.

The molecular formula of $\mathbf{1}$ was determined to be $\mathrm{C}_{31} \mathrm{H}_{51} \mathrm{~N}_{5} \mathrm{O}_{10}$. The amino acid constitution except 5-ATHH was Val $(2 \mathrm{~mol})$, Leu $(1 \mathrm{~mol})$ and $\beta$-Phe $(1 \mathrm{~mol})$. The sequence of Val-Val-Leu was clarified by Edman's degradation. Therefore, it was estimated that 1 had Val-Val binding to $N$-terminus of 3 . The sequence of five amino acids was confirmed by $\mathrm{HMBC}$ experiments and ${ }^{1} \mathrm{H}_{-}{ }^{13} \mathrm{C}$ long range coupling analysis. From these results, 1 was 
Fig. 2. Purification procedure for pyloricidins $B(2)$ and C (3).

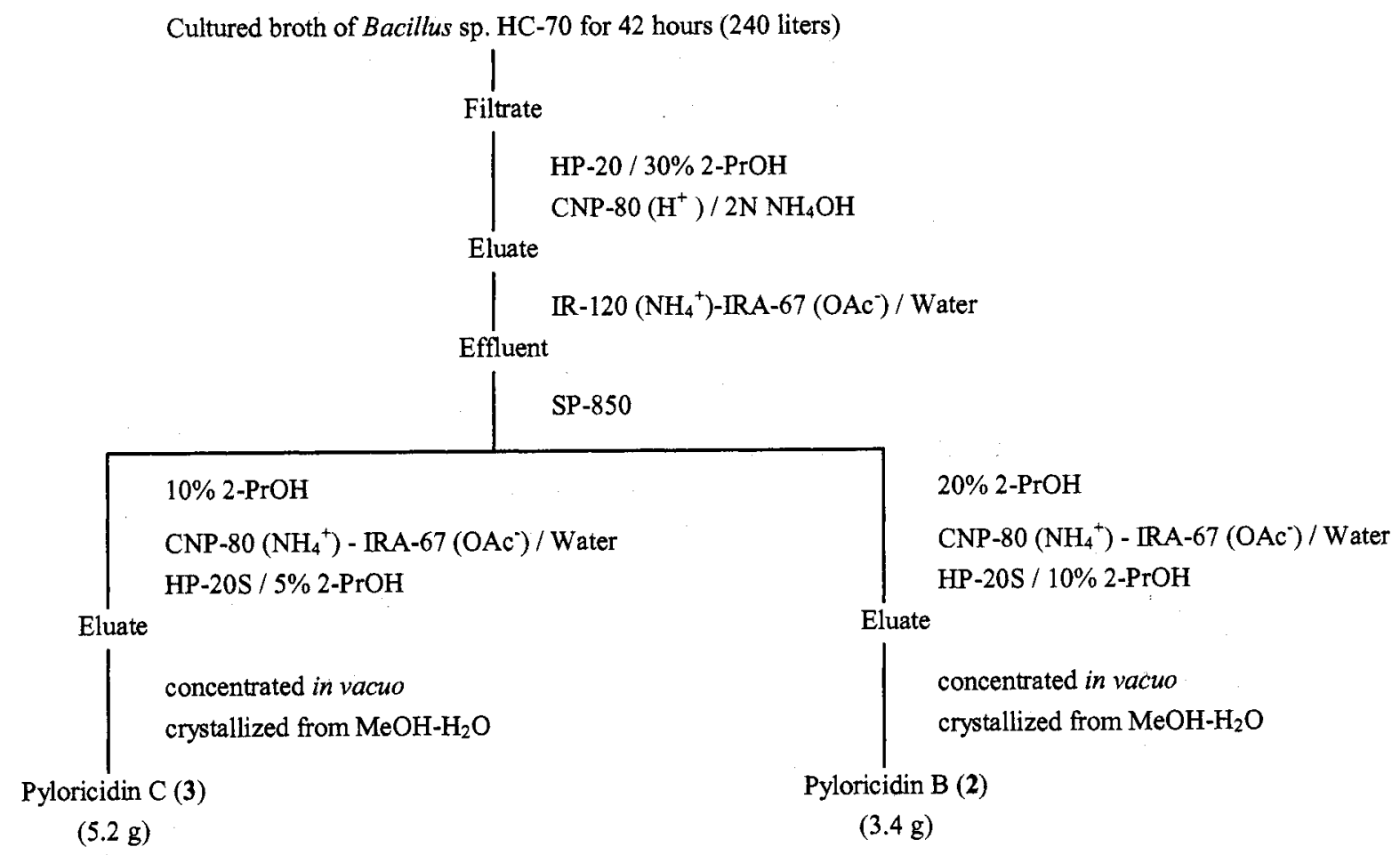

Fig. 3. 2D NMR data of pyloricidin C (3).

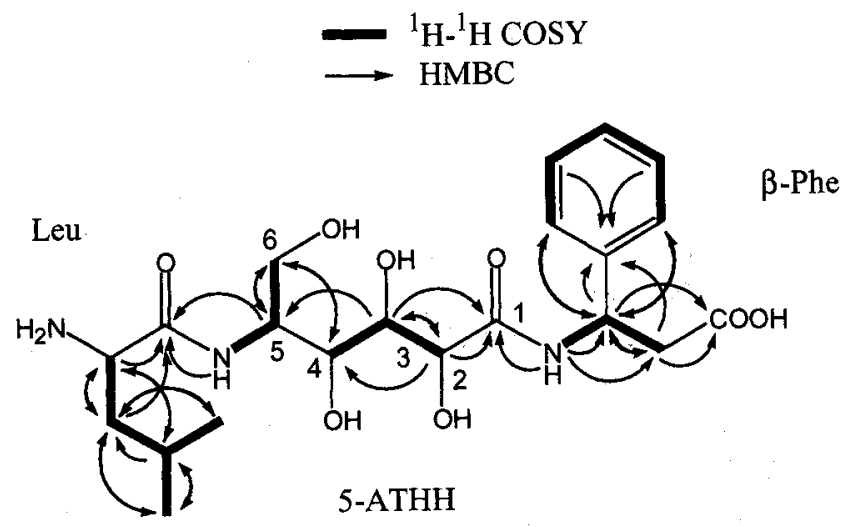

determined to be 3-[5-(valyl-valyl-leucyl)amino-2,3,4,6tetrahydroxyhexanoyl]amino-3-phenylpropionic acid.

Compounds $1 \mathrm{a}$ and $\mathbf{1 b}$, the minor products obtained from the crude crystals of $\mathbf{1}$, had an identical molecular formula of $\mathrm{C}_{32} \mathrm{H}_{53} \mathrm{~N}_{5} \mathrm{O}_{10}$. The amino acid constitutions except 5-ATHH were Val $(1 \mathrm{~mol})$, Ile $(1 \mathrm{~mol})$, Leu $(1 \mathrm{~mol})$ and $\beta$-Phe $(1 \mathrm{~mol})$ in 1a, and Val $(1 \mathrm{~mol})$, Leu $(2 \mathrm{~mol})$ and
$\beta$-Phe $(1 \mathrm{~mol})$ in $\mathbf{1 b}$. Therefore, it was suggested that one mole of Val in $\mathbf{1}$ was substituted by one mole of Ile in 1a and by one mole of Leu in $\mathbf{1 b}$. The sequences of these amino acids were elucidated by similar methods as described above and the structures of $\mathbf{1 a}$ and $\mathbf{1 b}$ were determined, as shown in Fig. 1.

The molecular formula of $\mathbf{2}$ was determined to be $\mathrm{C}_{26} \mathrm{H}_{42} \mathrm{~N}_{4} \mathrm{O}_{9}$. The amino acid constitution except 5-ATHH was Val $(1 \mathrm{~mol})$, Leu $(1 \mathrm{~mol})$ and $\beta$-Phe $(1 \mathrm{~mol})$. The sequence of the four amino acids was elucidated by ${ }^{1} \mathrm{H}^{13} \mathrm{C}$ long range :coupling analysis and the sequence of Val-Leu was confirmed by Edman's degradation analysis. These experiments clarified that $\mathbf{2}$ was 3-[5-(valyl-leucyl)amino2,3,4,6-tetrahydroxyhexanoyl]amino-3-phenylpropionic acid.

The molecular formula of $\mathbf{4}$ was determined to be $\mathrm{C}_{15} \mathrm{H}_{22} \mathrm{~N}_{2} \mathrm{O}_{7}$. The NMR data (Table 2) showed that 4 also contained 5-ATHH and $\beta$-Phe moieties. The amino acid analysis indicated that Leu observed in $\mathbf{3}$ was absent in 4. Upon treatment with pronase (Actinase E), 3 gave 4. These results suggested that $N$-terminal Leu in $\mathbf{3}$ was detached in 4. The ${ }^{1} \mathrm{H}_{-}{ }^{13} \mathrm{C}$ long range coupling analysis confirmed the structure of 4 to be 3-(5-amino-2,3,4,6tetrahydroxyhexanoyl)amino-3-phenylpropionic acid. 
Table 2-1. ${ }^{1} \mathrm{H}$ and ${ }^{13} \mathrm{C}$ NMR spectral data of pyloricidins A (1) and B (2) in DMSO- $d_{6}$.

\begin{tabular}{|c|c|c|c|c|c|c|c|}
\hline \multirow[b]{2}{*}{ Moiety } & \multirow[b]{2}{*}{ Position } & \multicolumn{3}{|c|}{ Pyloricidin A (1) } & \multicolumn{3}{|c|}{ Pyloricidin B (2) } \\
\hline & & $\delta \mathrm{C}$ & $\delta \mathrm{H}$ & $J(\mathrm{~Hz})$ & $\delta \mathrm{C}$ & $\delta \mathrm{H}$ & $J(\mathrm{~Hz})$ \\
\hline \multirow[t]{7}{*}{ L-Val } & $C=O$ & 172.64 & & & & & \\
\hline & 2 & 59.59 & 3.11 & $(1 \mathrm{H}, \mathrm{d}, J=4.8)$ & & & \\
\hline & 3 & 31.07 & 1.95 & $(1 \mathrm{H}, \mathrm{m})$ & & & \\
\hline & 4 & 16.81 & 0.79 & $(3 \mathrm{H}, \mathrm{d}, J=6.8)$ & & & \\
\hline & $4^{\prime}$ & 19.26 & 0.88 & $(3 \mathrm{H}, \mathrm{d}, J=6.2)$ & & & \\
\hline & $\mathrm{NH}_{2}$ & & nd & & & & \\
\hline & - & & & & & & \\
\hline \multirow[t]{6}{*}{$\mathrm{L}-\mathrm{Val}$} & $\mathrm{C}=\mathrm{O}$ & 170.86 & & & 173.00 & & \\
\hline & 2 & 57.35 & 4.19 & $(1 \mathrm{H}, \mathrm{d}, J=6.6)$ & 58.01 & 3.69 & $(1 \mathrm{H}, \mathrm{m})$ \\
\hline & 3 & 30.67 & 1.97 & $(1 \mathrm{H}, \mathrm{m})$ & 30.52 & 2.14 & $(1 \mathrm{H}, \mathrm{m})$ \\
\hline & 4 & 18.04 & 0.84 & $(3 \mathrm{H}, \mathrm{d}, J=6.8)$ & 17.90 & 0.98 & $(3 \mathrm{H}, \mathrm{d}, J=7.5)$ \\
\hline & $4^{\prime}$ & 19.33 & 0.871 & $(3 \mathrm{H}, \mathrm{d}, J=6.2)$ & 18.78 & 1.01 & $(3 \mathrm{H}, \mathrm{d}, J=6.8)$ \\
\hline & NH & & 8.00 & $(1 \mathrm{H}, \mathrm{br} \mathrm{s})$ & $\left(\mathrm{NH}_{3}{ }^{+}\right)$ & 8.07 & $(3 \mathrm{H}, \mathrm{brd}, J=4.2)$ \\
\hline \multirow[t]{7}{*}{ L-Leu } & $\mathrm{C}=\mathrm{O}$ & 172.42 & & & 168.30 & & \\
\hline & 2 & 51.15 & 4.33 & $(1 \mathrm{H}, \mathrm{m})$ & 51.98 & 4.52 & $(1 \mathrm{H}, \mathrm{m})$ \\
\hline & 3 & 40.59 & 1.50 & $(2 \mathrm{H}, \mathrm{dd}, J=6.4,7.1)$ & 41.47 & 1.57 & $(2 \mathrm{H}, \mathrm{t}$ like $)$ \\
\hline & 4 & 24.14 & 1.60 & $(1 \mathrm{H}, \mathrm{m})$ & 24.60 & 1.72 & $(1 \mathrm{H}, \mathrm{m})$ \\
\hline & 5 & 21.49 & 0.83 & $(3 \mathrm{H}, \mathrm{d}, J=6.3)$ & 21.93 & 0.93 & $(3 \mathrm{H}, \mathrm{d}, J=6.0)$ \\
\hline & $5^{\prime}$ & 22.96 & 0.869 & $(3 \mathrm{H}, \mathrm{d}, J=7.5)$ & 23.36 & 0.96 & $(3 \mathrm{H}, \mathrm{d}, J=6.0)$ \\
\hline & NH & & 8.02 & $(1 \mathrm{H}, \mathrm{d}, J=8.2)$ & & 8.51 & $(1 \mathrm{H}, \mathrm{d}, J=8.1)$ \\
\hline \multirow[t]{8}{*}{ 5-ATHH } & $\mathrm{C}=\mathrm{O}$ & 172.33 & & & 172.69 & & \\
\hline & 2 & 71.07 & 4.13 & $(1 \mathrm{H}, \mathrm{br} d, J=1)$ & 71.46 & 4.24 & $(1 \mathrm{H}, \mathrm{br} \mathrm{s})$ \\
\hline & 3 & 71.07 & 3.52 & $(1 \mathrm{H}, \mathrm{dd}, J=1,6.6)$ & 71.88 & 3.62 & $(1 \mathrm{H}, \mathrm{d}, J=9.6)$ \\
\hline & 4 & 67.75 & 3.77 & $(1 \mathrm{H}, \mathrm{d}, J=6.6)$ & 68.10 & 3.87 & $(1 \mathrm{H}, \mathrm{d}, J=9.6)$ \\
\hline & 5 & 51.30 & 4.00 & $(1 \mathrm{H}, \mathrm{m})$ & 51.98 & 4.10 & $(1 \mathrm{H}, \mathrm{m})$ \\
\hline & 6 & 60.72 & 3.39 & $(1 \mathrm{H}, \mathrm{dd}, J=6.0,10.1)$ & 62.00 & 3.48 & $(1 \mathrm{H}, \mathrm{dd}, J=6.2,9.8)$ \\
\hline & & & 3.44 & $(1 \mathrm{H}, \mathrm{dd}, J=8.1,10.1)$ & & 3.53 & $(1 \mathrm{H}, \mathrm{dd}, J=9.2,9.8)$ \\
\hline & NH & & 7.14 & $(1 \mathrm{H}, \mathrm{d}, J=8.7)$ & & 7.58 & $(1 \mathrm{H}, \mathrm{d}, J=8.7)$ \\
\hline \multirow[t]{9}{*}{ D- $\beta$-Phe } & $C=0$ & 173.68 & & & 173.26 & & \\
\hline & 2 & 41.34 & 2.64 & $(1 \mathrm{H}, \mathrm{dd}, J=6.9,15.5)$ & 40.79 & 2.81 & $(1 \mathrm{H}, \mathrm{dd}, \mathrm{J}=7.1,16.0)$ \\
\hline & & & 2.71 & $(1 \mathrm{H}, \mathrm{dd}, J=6.1,15.5)$ & & 2.89 & $(1 \mathrm{H}, \mathrm{dd}, \mathrm{J}=6.2,16.0)$ \\
\hline & 3 & 49.22 & 5.20 & $(1 \mathrm{H}, \mathrm{m})$ & 49.50 & 5.31 & $(1 \mathrm{H}, \mathrm{m})$ \\
\hline & 4 & 142.61 & & 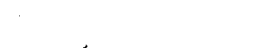 & 142.65 & & \\
\hline & 5,9 & 126.47 & 7.34 & $(2 \mathrm{H}, \mathrm{m})$ & 127.41 & 7.34 & $(2 \mathrm{H}, \mathrm{m})$ \\
\hline & 6,8 & 127.98 & 7.38 & $(2 \mathrm{H}, \mathrm{m})$ & 128.68 & 7.41 & $(2 \mathrm{H}, \mathrm{m})$ \\
\hline & 7 & 126.56 & 7.19 & $(1 \mathrm{H}, \mathrm{m})$ & 127.09 & 7.25 & $(1 \mathrm{H}, \mathrm{m})$ \\
\hline & $\mathrm{NH}$ & & 8.22 & $(1 \mathrm{H}, \mathrm{d}, J=8.6)$ & & 8.24 & $(1 \mathrm{H}, \mathrm{d}, J=8.8)$ \\
\hline
\end{tabular}

* pyloricidin B (2) was measured in DMSO- $d_{6}$ : trifluoroacetic acid (9:1)

Absolute Stereochemistry

Absolute configurations of Val, Leu and lle were determined by HPLC analysis using a chiral column. The results showed that all $\alpha$-amino acids were L-forms. Acid hydrolysis of 1 gave $\beta$-Phe (5) in addition to a tripeptide L-Val-L-Val-L-Leu (6). The optical rotation of 5 was levorotatory: $\left.[\alpha]_{D}^{24}-7.5^{\circ}(c) 0.65, \mathrm{H}_{2} \mathrm{O}\right)$. Therefore, the 
Table 2-2. ${ }^{1} \mathrm{H}$ and ${ }^{13} \mathrm{C}$ NMR spectral data of pyloricidins $\mathrm{C}(3)$ and $\mathrm{D}(4)$ in DMSO- $d_{6}$.

\begin{tabular}{|c|c|c|c|c|c|c|c|}
\hline \multirow[b]{2}{*}{ Moiety } & \multirow[b]{2}{*}{ Position } & \multicolumn{3}{|c|}{ Pyloricidin C (3) } & \multicolumn{3}{|c|}{ Pyloricidin D (4) } \\
\hline & & $8 \mathrm{C}$ & $\delta \mathrm{H}$ & $J(\mathrm{~Hz})$ & $8 \mathrm{C}$ & $8 \mathrm{H}$ & $J(\mathrm{~Hz})$ \\
\hline \multirow[t]{8}{*}{ L-Leu } & $C=O$ & 174.27 & & & & & \\
\hline & 2 & 52.30 & 3.35 & $(1 \mathrm{H}, \mathrm{m})$ & & & \\
\hline & 3 & 42.71 & 1.29 & $(1 \mathrm{H}, \mathrm{ddd}, J=5.2,9.0,13.6)$ & & & \\
\hline & & & 1.48 & $(1 \mathrm{H}$, ddd, $J=4.9,8.6,13.6)$ & & & \\
\hline & 4 & 23.86 & 1.72 & $(1 \mathrm{H}, \mathrm{m})$ & & & \\
\hline & 5 & 21.66 & 0.87 & $(3 \mathrm{H}, \mathrm{d}, J=6.6)$ & & & \\
\hline & $5^{\prime}$ & 23.04 & 0.88 & $(3 \mathrm{H}, \mathrm{d}, J=6.7)$ & & & \\
\hline & $\mathrm{NH}_{2}$ & & nd & & & & \\
\hline \multirow[t]{8}{*}{ 5-ATHH } & $\mathrm{C}=\mathrm{O}$ & 172.39 & & & 172.32 & & \\
\hline & 2 & 70.74 & 4.13 & $(1 \mathrm{H}, \mathrm{br} \mathrm{s})$ & 70.82 & 4.15 & $(1 \mathrm{H}, \mathrm{br} \mathrm{s})$ \\
\hline & 3 & 71.21 & 3.52 & $(1 \mathrm{H}, \mathrm{d}, J=9.8)$ & 71.38 & 3.78 & $(1 \mathrm{H}, \mathrm{d}, J=9.4)$ \\
\hline & 4 & 67.63 & 3.77 & $(1 \mathrm{H}, \mathrm{d}, J=9.8)$ & 66.59 & 3.65 & $(1 \mathrm{H}, \mathrm{d}, J=9.4)$ \\
\hline & 5 & 51.22 & 3.99 & $(1 \mathrm{H}, \mathrm{m})$ & 53.34 & 3.26 & $(1 \mathrm{H}, \mathrm{m}$ or $\mathrm{t}$ like $)$ \\
\hline & 6 & 60.92 & 3.43 & $(2 \mathrm{H}, \mathrm{m})$ & 60.89 & 3.49 & $(1 \mathrm{H}, \mathrm{dd}, J=6.3,11.0)$ \\
\hline & & & & & & 3.53 & $(1 \mathrm{H}, \mathrm{dd}, J=5.8,11.0)$ \\
\hline & NH & & 7.85 & $(1 \mathrm{H}, \mathrm{d}, J=8.3)$ & & nd & \\
\hline \multirow[t]{9}{*}{$D-\beta-P h e$} & $C=0$ & 172.69 & & & 175.06 & & \\
\hline & 2 & 41.30 & 2.67 & $(1 \mathrm{H}, \mathrm{dd}, J=6.7,15.6)$ & 43.11 & 2.49 & $(2 \mathrm{H}, \mathrm{m})$ \\
\hline & & & 2.72 & $(1 \mathrm{H}, \mathrm{dd}, J=6.3,15.6)$ & & & \\
\hline & 3 & 49.01 & 5.19 & $(1 \mathrm{H}, \mathrm{m})$ & 49.69 & 5.08 & $(1 \mathrm{H}, \mathrm{m})$ \\
\hline & 4 & 142.66 & & & 143.43 & & \\
\hline & 5,9 & 126.46 & 7.32 & $(2 \mathrm{H}, \mathrm{m})$ & 126.32 & 7.32 & $(2 \mathrm{H}, \mathrm{m})$ \\
\hline & 6,8 & 127.92 & 7.28 & $(2 \mathrm{H}, \mathrm{m})$ & 127.85 & 7.20 & $(2 \mathrm{H}, \mathrm{m})$ \\
\hline & 7 & 126.46 & 7.21 & $(1 \mathrm{H}, \mathrm{m})$ & 126.20 & 7.14 & $(1 \mathrm{H}, \mathrm{m})$ \\
\hline & NH & & 8.34 & $(1 \mathrm{H}, \mathrm{d}, J=8.7)$ & & 8.94 & $(1 \mathrm{H}, \mathrm{d}, J=8.7)$ \\
\hline
\end{tabular}

configuration of $\mathbf{5}$ was determined to be $\mathrm{D}$-form in comparison with the optical rotation values of the reference compounds, $\mathrm{L}(+)$ - $\beta$-phenylalanine; $[\alpha]_{\mathrm{D}}^{22}+10.6^{\circ}(c \quad 0.65$, $\left.\mathrm{H}_{2} \mathrm{O}\right)^{7)}$.

The absolute configurations of 5-ATHH moiety were still unknown. The crystals of pyloricidins and their derivatives, such as $\mathrm{N}$-4-bromobenzoates were not suitable for a single $\mathrm{X}$-ray diffraction analysis. However, a degradation experiment provided crystals suitable for X-ray analysis. The acid hydrolysis of 4 afforded 5-ATHH (7) and its $\delta$ lactam compound (8) as shown in Fig. 4. Crystallization of the mixture containing 7 and 8 from EtOH $-\mathrm{H}_{2} \mathrm{O}$ gave colorless prisms of $\mathbf{8}$. The structure of $\mathbf{8}$ including the relative stereochemistry and the absolute configuration was determined by X-ray analyses. As this compound contains only light elements up to oxygen, the intensity data were carefully measured to determine the right enantiomer from their small anomalous differences. Three crystals grown from the same batch were reshaped to spheres, and subjected to the analyses. Table 3 summarizes the crystal data and the structure refinement parameters. Although the estimated standard deviations exceeded the ideal range, the Flack parameters ${ }^{8)}$ in the three independent analyses fell into the same trend. Thus the absolute structure of 8 depicted in Fig. 5 was supported.

In addition, the absolute configuration of $\mathrm{C}-4$ position was confirmed by an application of modified Mosher's method $^{9)}$. 4-Hydroxy derivative (10) was prepared from 7 through a $\gamma$-lactone compound (9), as shown in Fig. 6. Then $(S)$ and (R)-2-methoxy-2-phenyl-2(trifluoromethyl)acetic acid (MTPA) esters (11a and 11b, respectively) of $\mathbf{1 0}$ were synthesized. By analysis of 
Fig. 4. Degradation and modification studies of pyloricidins.

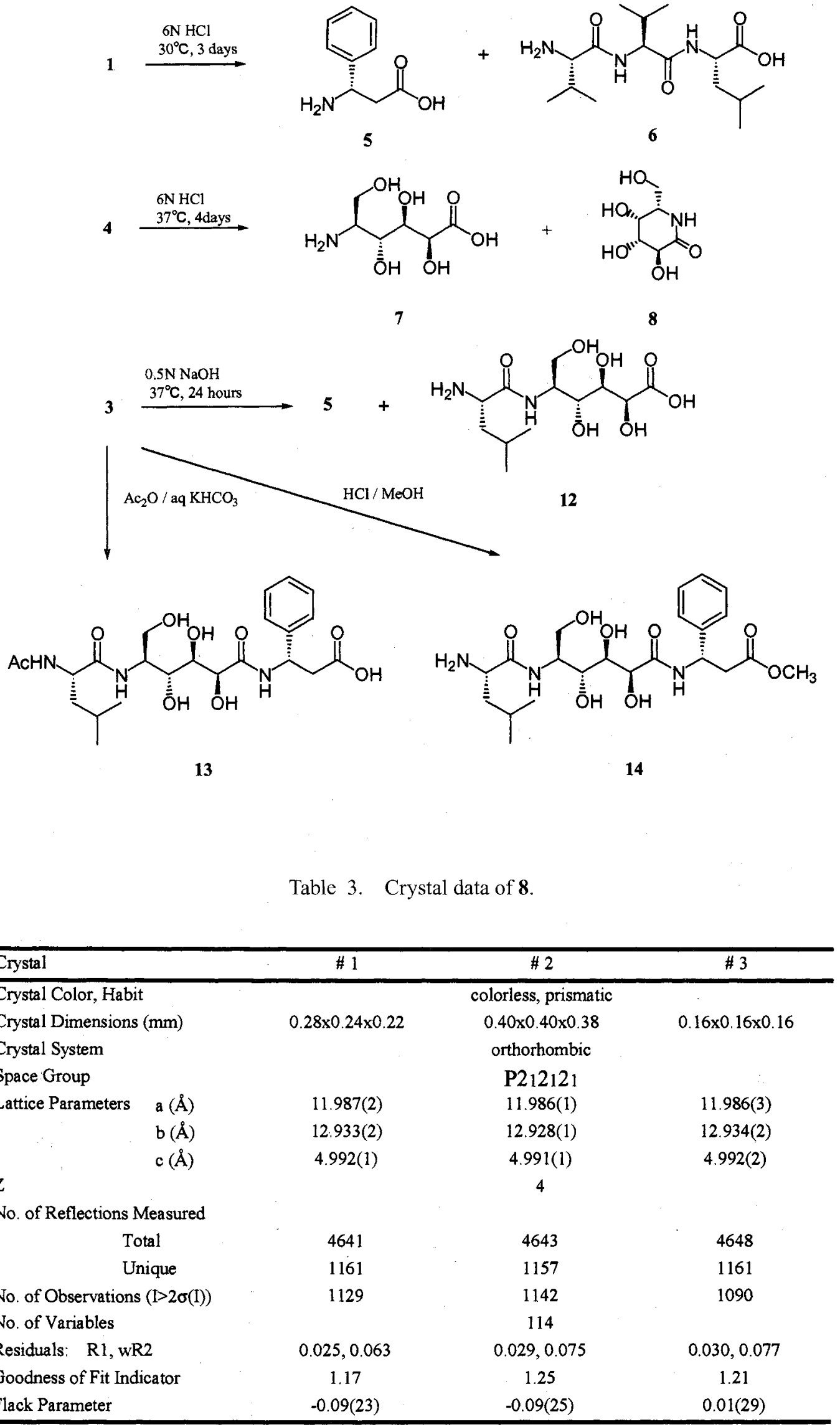


chemical shift differences (Fig. 7) in ${ }^{1} \mathrm{H}$ NMR spectra of $11 \mathbf{a}$ and $11 \mathbf{b}$, the absolute configuration of $\mathrm{C}-4$ was assigned to $R$. This result was coincident with that of the X-ray analyses. Thus, the absolute structure of $\mathbf{8}$ was determined to be $(3 S, 4 R, 5 R, 6 S)$-3,4,5-trihydroxy-6hydroxymethylpiperidine-2-one. Finally, the absolute structure of 7 was determined to be $(2 S, 3 R, 4 R, 5 S)-5$ amino-2,3,4,6-tetrahydroxyhexanoic acid.

\section{Aniti-H. pylori Activity of Degradation and Modification Products}

Degradation products $(\mathbf{5} \sim \mathbf{8})$ described in the section of structure elucidation did not show anti- $H$. pylori activity (MIC $>128 \mu \mathrm{g} / \mathrm{ml}$ ). Furthermore, 5-leucylamino-2,3,4,6tetrahydroxyhexanoic acid (12) which was obtained by mild alkaline hydrolysis of 3 was also inactive (Fig. 4). All of these data indicated that $\mathbf{4}$ was a minimum structure for anti- $H$. pylori activity. In addition, an $N$-acetylated derivative (13) and a methyl ester derivative (14) of 3 did not show activity. This data suggested that both a primary amine at $N$-terminal and a carboxyl at $\beta$-Phe are essential for anti-H. pylori activity.

\section{Discussion}

Quinolone derivatives ${ }^{10,11)}$, brefedlin $\mathrm{A}^{12)}$ and $\mathrm{CJ}-$

Fig. 7. Chemical shift differences obtained from $11 \mathrm{a}$ and $11 \mathrm{~b}$.

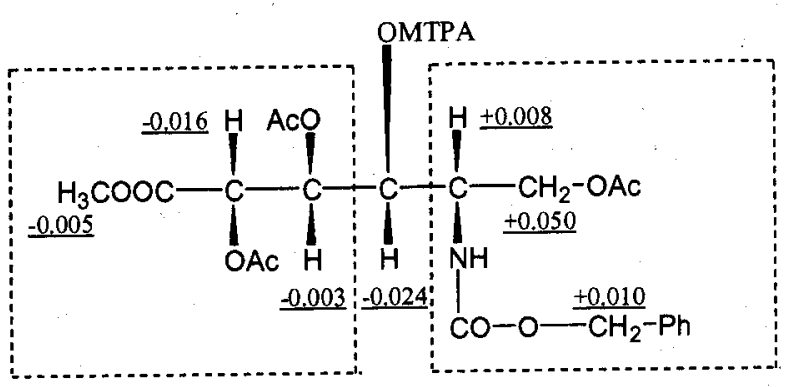

Figures showed $\Delta \delta\left(\delta_{11 \mathrm{a}}-\delta_{11 \mathrm{~b}}\right)$

Fig. 6. Synthesis of MTPA esters (11a and 11b).

Displacement ellipsoids are plotted at the 50\% probability level for non-hydrogen atoms.

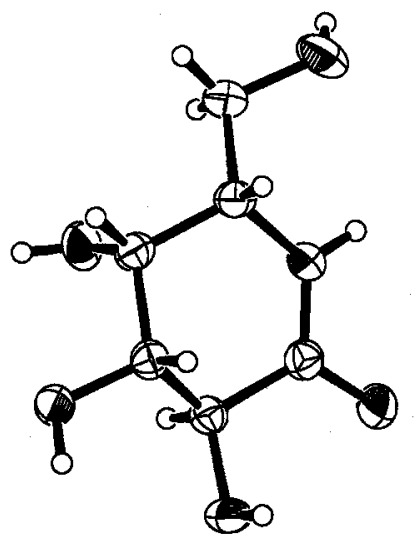


$12,954^{13)}$ were already reported as anti-H. pylori compounds. Pyloricidins were peptide-like compounds that contained two unusual amino acids, viz., $(2 S, 3 R, 4 R, 5 S)-5$ amino-2,3,4,6-tetrahydroxyhexanoic acid and D- $\beta$-Phe. Pyloricidins are the first peptide-like antibiotics active against $H$. pylori.

The structure-activity relationship of degradation products indicated that 4 was a minimum structure for antiH. pylori activity. Comparing activities of $\mathbf{1}, \mathbf{1 a}, \mathbf{1 b}$ and $\mathbf{2}$ with those of 3 and 4 , the addition of di- or tripeptide at $\mathrm{N}$ terminal of 4 increased the activity ${ }^{6)}$. This suggests that modification of $\mathrm{N}$-terminal moiety with oligopeptides is promising. Pyloricidins in this study could provide useful information for the synthesis of new anti- $H$. pylori agents.

\section{Experimental}

\section{General}

IR spectra were obtained on a HORIBA FT-200 FT-IR infrared spectrometer. UV spectra were recorded on a HITACHI U-3200 spectrophotometer. Optical rotations were measured on a JASCO DIP-360 digital polarimeter. ${ }^{1} \mathrm{H}(300 \mathrm{MHz})$ and ${ }^{13} \mathrm{C}$ NMR $(75 \mathrm{MHz})$ spectra were recorded on a BRUKER AC300 NMR spectrometer or a BRUKER DPX300 NMR spectrometer in DMSO- $d_{6}$ solution unless otherwise stated. Trimethylsilane was used as an internal standard $(0 \mathrm{ppm})$. TLC was performed on Kieselgel $60 \mathrm{~F}_{254}$, using $n-\mathrm{BuOH}-\mathrm{AcOH}-\mathrm{H}_{2} \mathrm{O} \quad 12: 3: 5$ $(\mathrm{v} / \mathrm{v} / \mathrm{v})$. HPLC analyses were carried out using a column of YMC-Pack ODS-A, A-312 (i.d. $6.0 \mathrm{~mm} \times 150 \mathrm{~mm}$ ) with a flow rate of $1 \mathrm{ml} /$ minute. Evaporations were carried out in vacuo at $\leqq 40^{\circ} \mathrm{C}$.

\section{Isolation of $\mathbf{1}, \mathbf{1 a}$ and $\mathbf{1 b}$ from Bacillus sp. HC-70}

The filtrate of the fermentation broth (250 liters) of Bacillus sp. HC-70 cultured for 30 hours was adjusted to pH 6.0 and applied to a column of Diaion HP-20 (15 liters, Mitsubishi Chemical Industries). The column was washed with water (45 liters) and eluted with $30 \%$ aqueous 2-PrOH (60 liters). The eluate was successively loaded onto a column of Lewatit CNP-80 $\left(\mathrm{H}^{+}\right.$form, 20 liters, Bayer). After washing with water (60 liters), active substances were eluted with $2 \mathrm{~N}$ aqueous $\mathrm{NH}_{4} \mathrm{OH}$ (80 liters). The eluate was concentrated to $c a$. 9.5 liters and applied to columns of Amberlite IR-120 $\left(\mathrm{NH}_{4}{ }^{+}\right.$form, 1.5 liters, Rohm \& Haas company), Amberlite IRA-67 (OAc ${ }^{-}$form, 1.5 liters, Rohm \& Haas company) and Sepabeads SP-850 (2 liters, Mitsubishi Chemical Industries) in series. After washing with water ( 8 liters), the column of SP-850 was further washed with $0.2 \mathrm{~N}$ aqueous $\mathrm{NH}_{4} \mathrm{OH}$ (2 liters), water (6 liters), $0.1 \mathrm{~N}$ aqueous $\mathrm{HCl}$ (2 liters), water (6 liters) and 5\% aqueous 2-PrOH (6 liters) successively, and then eluted with $20 \%$ aqueous 2 -PrOH (8 liters) and $30 \%$ aqueous $2-$ PrOH (6 liters). The combined active fraction was passed through columns of IR-120 $\left(\mathrm{NH}_{4}^{+}\right.$form, 0.5 liter $)$ and of IRA-67 (OAc ${ }^{-}$form, 0.5 liter) and washed with water (2 liters). The effluent (12.5 liters) was concentrated in vacuo to give the crude crystals $(9.6 \mathrm{~g})$ of $\mathbf{1}$, which contained 1a and $\mathbf{1 b}$ as minor products. The crude crystals of $\mathbf{1}$ were further purified by preparative reversed phase HPLC (column, YMC -GEL KE-ODS-10S i.d. $50 \mathrm{~mm} \times 300 \mathrm{~mm}$; mobile phase, $\mathrm{CH}_{3} \mathrm{CN}-20 \mathrm{~mm} \mathrm{KH}_{2} \mathrm{PO}_{4}$ 17:83; flow rate, $30 \mathrm{ml} /$ minute; detection, UV $214 \mathrm{~nm}$ ). (i) Fractions containing 1 were loaded on a column of HP-20 $(250 \mathrm{ml})$ and the column was washed with water $(750 \mathrm{ml})$, and then eluted with $20 \%$ aqueous 2-PrOH $(250 \mathrm{ml})$ and $0.1 \mathrm{~N}$ $\mathrm{NH}_{4} \mathrm{OH} / 20 \%$ aqueous 2-PrOH $(750 \mathrm{ml})$. The eluate containing 1 was concentrated in vacuo and recrystallized from water to yield crystals of $1(4.49 \mathrm{~g})$.

(ii) Fractions containing 1a were desalted by almost the same procedure as described in (i) to give crystals of 1a (249 mg); Anal. Calcd for $\mathrm{C}_{32} \mathrm{H}_{53} \mathrm{~N}_{5} \mathrm{O}_{10} \cdot 2 \mathrm{H}_{2} \mathrm{O}: \mathrm{C} 54.61, \mathrm{H}$ 8.16, N 9.95. Found: C 54.54, H 8.16, N 10.12; FAB-MS $m / z 668[\mathrm{M}+\mathrm{H}]^{+} ;{ }^{13} \mathrm{C}$ NMR $\delta 10.84(\mathrm{q}), 15.32(\mathrm{q}), 16.90$ (q), 18.98 (q), 21.28 (q), 23.06 (q), 23.98 (d), 24.30 (t), 30.85 (d), 36.72 (d), $40.48(\mathrm{t}), 41.16(\mathrm{t}), 48.99$ (d), 50.82 (d), 51.11 (d), 56.49 (d), 58.82 (d), 60.46 (t), 67.18 (d), 70.83 (d), 71.03 (d), $126.47(\mathrm{~d} \times 3), 127.95(\mathrm{~d} \times 2), 142.60$ (s), $170.78(\mathrm{~s}), 172.22$ (s), 172.35 (s), 172.38 (s), 172.71 (s); TLC, $\mathrm{Rf}=0.51$. HPLC, $\mathrm{Rt}=27.0$ minutes. Solvent system: $\mathrm{CH}_{3} \mathrm{CN}-20 \mathrm{mM} \mathrm{KH}_{2} \mathrm{PO}_{4} 15: 85$.

(iii) Fractions containing $\mathbf{1 b}$ were concentrated and recrystallized from water to yield crystals of $\mathbf{1 b}(400 \mathrm{mg})$; Anal. Calcd for $\mathrm{C}_{32} \mathrm{H}_{53} \mathrm{~N}_{5} \mathrm{O}_{10} \cdot 3.5 \mathrm{H}_{2} \mathrm{O}: \mathrm{C} 52.59, \mathrm{H} 8.27, \mathrm{~N}$ 9.58. Found: C 52.59, H 8.03, N 9.78; FAB-MS $m / z 668$ $[\mathrm{M}+\mathrm{H}]^{+} ;{ }^{13} \mathrm{C}$ NMR $\delta 16.95(\mathrm{q}), 19.01(\mathrm{q}), 21.25(\mathrm{q}), 21.58$ (q), $22.92(\mathrm{q}), 23.06(\mathrm{q}), 24.07(\mathrm{~d} \times 2), 30.85$ (d), $40.43(\mathrm{t})$, $40.94(\mathrm{t}), 41.24(\mathrm{t}), 49.07(\mathrm{~d}), 50.65(\mathrm{~d}), 51.03(\mathrm{~d} \times 2), 59.00$ (d), $60.47(\mathrm{t}), 67.20(\mathrm{~d}), 70.77(\mathrm{~d}), 71.00(\mathrm{~d}), 126.45(\mathrm{~d} \times 2)$, 126.50 (d), $127.95(\mathrm{~d} \times 2), 172.30(\mathrm{~s} \times 2), 172.45(\mathrm{~s}), 172.78$ (s), $172.86(\mathrm{~s})$; TLC, $\mathrm{Rf}=0.54$. HPLC, Rt=39.0 minutes. Solvent system: $\mathrm{CH}_{3} \mathrm{CN}-20 \mathrm{mM} \mathrm{KH}_{2} \mathrm{PO}_{4} 15: 85$.

\section{Isolation of $\mathbf{2}$ and $\mathbf{3}$ from Bacillus sp. HC-70}

The procedure for isolation of $\mathbf{2}$ and $\mathbf{3}$ is shown in Fig. 2. The filtrate of the fermentation broth (240 liters) of Bacillus sp. HC-70 cultured for 42 hours was adjusted to $\mathrm{pH} 7.0$ and loaded onto a column of HP-20 (15 liters). After washing with water (45 liters), the active compounds were eluted 
with $30 \%$ aqueous $2-\mathrm{PrOH}$ (60 liters). Then the eluate was subjected to a column of $\mathrm{CNP}-80$ ( $\mathrm{H}^{+}$form, 20 liters) and the column was washed with water (60 liters) and eluted with $2 \mathrm{~N}$ aqueous $\mathrm{NH}_{4} \mathrm{OH}$ (80 liters). The eluate was successively concentrated to $c a .8 .8$ liters and applied to columns of IR-120 $\left(\mathrm{NH}_{4}{ }^{+}\right.$form, 1.5 liters), IRA-67 (OAc ${ }^{-}$ form, 1.5 liters) and SP-850 (2 liters) in series. After washing the columns with water ( 8 liters), the column of SP-850 was further washed with $0.1 \mathrm{~N}$ aqueous $\mathrm{HCl}$ (2 liters), water (6 liters) and 5\% aqueous 2-PrOH (6 liters) successively, and then eluted with $10 \%$ aqueous $2-\mathrm{PrOH}(6$ liters) to give fractions containing 3 , and $20 \%$ aqueous 2-PrOH (4 liters) to give fractions containing 2.

(i) Fractions containing 3 were concentrated to $c a .1 .3$ liters and passed through columns of CNP-80 $\left(\mathrm{NH}_{4}{ }^{+}\right.$form, $100 \mathrm{ml})$ and IRA-67 $\left(\mathrm{OAc}^{-}\right.$form, $\left.100 \mathrm{ml}\right)$ and washed with water $(400 \mathrm{ml})$. The effluent $(1.7$ liters $)$ was applied to a column of Diaion HP-20S (1 liter, Mitsubishi Chemical Industries). After washing with water (3 liters) and $2 \%$ aqueous $2-\mathrm{PrOH}$ ( 3 liters) successively, 3 was eluted with $5 \%$ aqueous $2-\mathrm{PrOH}$ (4 liters). The eluate was concentrated and crystallized from $\mathrm{MeOH}-\mathrm{H}_{2} \mathrm{O}(2: 1)$ to give crystals of $3(5 . \dot{2} \mathrm{~g})$.

(ii) Fractions containing 2 were purified by almost the same procedure as described in (i) to afford crystals of $\mathbf{2}$ (3.4 g).

\section{Isolation of $\mathbf{3}$ and $\mathbf{4}$ from Bacillus sp. HC-72}

The filtrate of the fermentation broth (1620 liters) of Bacillus sp. HC-72 cultured for 90 hours was applied to a column of Sepabeads SP-207 (75 liters, Mitsubishi Chemical Industries). The column was washed with water (225 liters), and eluted with $30 \%$ aqueous $2-\mathrm{PrOH}(300$ liters). The eluate was subjected to columns of IRA-67 (OAc ${ }^{-}$form, 8 liters) and CNP-80 ( $\mathrm{H}^{+}$form, 45 liters) in series. After washing the columns with water (300 liters), the column of CNP-80 was eluted with $2 \mathrm{~N}$ aqueous $\mathrm{NH}_{4} \mathrm{OH}$ (135 liters). The eluate was concentrated to $c a .10$ liters and applied to columns of IRA-67 (OAc ${ }^{-}$form, 2 liters) and SP-207 (3 liters) successively. After the columns were washed with water ( 9 liters), the column of SP-207 was eluted with $5 \%$ aqueous $2-\mathrm{PrOH}$ ( 8 liters) to give a fraction containing mainly 4 and then with $15 \%$ aqueous 2-PrOH (15 liters) to give a fraction containing mainly 3 . Both fractions were separately re-chromatographed on SP-207 to afford a fraction containing $\mathbf{4}$ and a fraction containing 3. The former fraction was concentrated and crystallized from EtOH $-\mathrm{H}_{2} \mathrm{O}(5: 1)$ to give colorless needles of 4 ( $28.4 \mathrm{~g})$.

The latter fraction was concentrated and crystallized from $\mathrm{MeOH}-\mathrm{H}_{2} \mathrm{O}(2: 1)$ to give colorless needles of 3 $(8.4 \mathrm{~g})$.

\section{Preparation of 4 by Enzymatic Conversion from 3}

To a solution of $3(3.0 \mathrm{~g}, 6.59 \mathrm{mmol})$ in $40 \mathrm{~mm}$ potassium phosphate buffer ( $\mathrm{pH} 8.0,750 \mathrm{ml}$ ) containing $4 \mathrm{mM} \mathrm{CoCl}_{2}$, Actinase E $(300 \mathrm{mg}, 300,000$ units, Kaken Pharmaceutical Co., Ltd.) was added. The reaction mixture was incubated at $37^{\circ} \mathrm{C}$ for 2 hours, and the insoluble material was removed by filtration. The filtrate was adjusted to $\mathrm{pH} 6.0$ and applied to a column of SP-207 $(200 \mathrm{ml})$. The column was washed with water $(600 \mathrm{ml})$, and eluted with $10 \%$ aqueous 2 -PrOH $(600 \mathrm{ml})$. The eluate was concentrated and crystallized from EtOH $-\mathrm{H}_{2} \mathrm{O}$ to give colorless needles of 4 (1.66 g, yield $74 \%$ ). The physico-chemical data were identical with those of the natural product (4).

\section{Preparation of $\mathbf{5}$ and $\mathbf{6}$ from $\mathbf{1}$}

A solution of $1(653 \mathrm{mg}, 1.0 \mathrm{mmol})$ in $6 \mathrm{~N} \mathrm{HCl}(65 \mathrm{ml})$ was maintained at $30^{\circ} \mathrm{C}$ for 3 days. The reaction mixture was adjusted to $\mathrm{pH} 6.0$ and applied to a column of SP-207 $(100 \mathrm{ml})$. The column was washed with water $(300 \mathrm{ml})$ and then eluted with $5 \%$ aqueous $2-\mathrm{PrOH}(300 \mathrm{ml}), 10 \%$ aqueous 2-PrOH $(300 \mathrm{ml})$ and $30 \%$ aqueous $2-\mathrm{PrOH}$ $(300 \mathrm{ml})$ successively. (i) The elute $(300 \mathrm{ml})$ of $5 \% 2-\mathrm{PrOH}$ was concentrated, and crystallized from water to give colorless needles of $5(63 \mathrm{mg}, 38 \%$ yield $) ;[\alpha]_{\mathrm{D}}^{24}-7.5^{\circ}$ (c $0.65, \mathrm{H}_{2} \mathrm{O}$ ); TLC, $\mathrm{Rf}=0.41$. HPLC, $\mathrm{Rt}=4.3$ minutes. Solvent system: $\mathrm{CH}_{3} \mathrm{CN}-20 \mathrm{mM} \mathrm{KH}_{2} \mathrm{PO}_{4} 7.5: 92.5$ (v/v).

(ii) The eluate $(600 \mathrm{ml})$ of $10 \%$ and $30 \%$ aqueous 2 PrOH was concentrated and chromatographed on a column of Sephadex G-10 (550 ml, Pharmacia) eluting with water. Fractions containing $\mathbf{6}$ were concentrated and then crystallized from water to give colorless needles of $\mathbf{6}$ (108 mg, 33\% yield); ${ }^{1} \mathrm{H}$ NMR $\delta 0.78(3 \mathrm{H}, \mathrm{d}, J=6.8 \mathrm{~Hz})$, $0.82(3 \mathrm{H}, \mathrm{d}, J=6.4 \mathrm{~Hz}), 0.83(3 \mathrm{H}, \mathrm{d}, J=6.7 \mathrm{~Hz}), 0.87(6 \mathrm{H}$, d, $J=6.5 \mathrm{~Hz}), 0.88(3 \mathrm{H}, \mathrm{d}, J=6.9 \mathrm{~Hz}), 1.49(2 \mathrm{H}, \mathrm{m}), 1.60$ $(1 \mathrm{H}, \mathrm{m}), 1.95(1 \mathrm{H}, \mathrm{m}), 1.97(1 \mathrm{H}, \mathrm{m}), 3.12(1 \mathrm{H}, \mathrm{d}$, $J=5.0 \mathrm{~Hz}), 4.15(1 \mathrm{H}, \mathrm{m}), 4.20(1 \mathrm{H}, \mathrm{m}), 8.01(1 \mathrm{H}$, br s$)$, $8.06(1 \mathrm{H}, \mathrm{d}, J=7.9 \mathrm{~Hz})$; FAB-MS $m / z 330[\mathrm{M}+\mathrm{H}]^{+}$; TLC, $\mathrm{Rf}=0.55$. HPLC, $\mathrm{Rt}=15.8$ minutes. Solvent system: $\mathrm{CH}_{3} \mathrm{CN}-20 \mathrm{mM} \mathrm{KH}_{2} \mathrm{PO}_{4} 7.5: 92.5$.

\section{Preparation of 5 and $\mathbf{1 2}$ from 3}

A solution of $3(910 \mathrm{mg}, 2.0 \mathrm{mmol})$ in $0.5 \mathrm{~N} \mathrm{NaOH}$ $(200 \mathrm{ml})$ was allowed to stand for 24 hours at $37^{\circ} \mathrm{C}$. The reaction mixture was adjusted to $\mathrm{pH} 5.0$ and loaded onto a column of SP-207 $(100 \mathrm{ml})$. The column was washed with water $(300 \mathrm{ml})$ and then eluted with $5 \%$ aqueous $2-\mathrm{PrOH}$ $(300 \mathrm{ml})$. (i) The passed and washed fractions were 
combined and applied to a column of activated charcoal $\mathrm{LH}_{2} \mathrm{C}$ ( $70 \mathrm{ml}$, Takeda Chemical Industries). The column was washed with water $(210 \mathrm{ml})$ and eluted with $10 \%$ aqueous 2-PrOH $(210 \mathrm{ml})$. The eluate was concentrated and chromatographed on a column of Sephadex G-10 $(550 \mathrm{ml})$ developing with water. Fractions containing $\mathbf{1 2}$ were concentrated and then crystallized from EtOH $-\mathrm{H}_{2} \mathrm{O}$ to give colorless needles of 12 (301 mg, 49\% yield); ${ }^{1} \mathrm{H}$ NMR $\delta$ $0.86(3 \mathrm{H}, \mathrm{d}, J=7.1 \mathrm{~Hz}), 0.89(3 \mathrm{H}, \mathrm{d}, J=7.3 \mathrm{~Hz}), 1.36(1 \mathrm{H}$, $\mathrm{m}), 1.49(1 \mathrm{H}, \mathrm{m}), 1.67(1 \mathrm{H}, \mathrm{m}), 3.30(1 \mathrm{H}, \mathrm{dd}, J=3.9$, $9.3 \mathrm{~Hz}), 3.38(1 \mathrm{H}, \mathrm{dd}, J=6.3,9.8 \mathrm{~Hz}), 3.43(1 \mathrm{H}, \mathrm{dd}, J=9.3$, $9.8 \mathrm{~Hz}), 3.58(1 \mathrm{H}, \mathrm{m}), 3.70(1 \mathrm{H}, \mathrm{d}, J=9.3 \mathrm{~Hz}), 3.85(1 \mathrm{H}, \mathrm{d}$, $J=3.9 \mathrm{~Hz}), 4.05(1 \mathrm{H}, \mathrm{d}$ like $), 7.90(1 \mathrm{H}, \mathrm{d}, J=8.6 \mathrm{~Hz})$; FABMS $m / z 309[\mathrm{M}+\mathrm{H}]^{+} ;$TLC, $\mathrm{Rf}=0.09 . \quad \mathrm{HPLC}, \mathrm{Rt}=2.8$ minutes. Solvent system: $\mathrm{CH}_{3} \mathrm{CN}-20 \mathrm{mM} \quad \mathrm{KH}_{2} \mathrm{PO}_{4}$ $7.5: 92.5(\mathrm{v} / \mathrm{v})$.

(ii) The eluate of $5 \%$ aqueous $2-\mathrm{PrOH}$ was concentrated and crystallized from water to give colorless needles of 5 (182 mg, 55\% yield).

\section{Analysis of Amino Acids}

(a) Amino acid analysis

Each compound of pyloricidins (ca. $0.5 \mathrm{mg}$ ) was completely hydrolyzed with $6 \mathrm{~N} \mathrm{HCl}$ for $24 \sim 72$ hours. The hydrolysates were evaporated to dryness and dissolved in $0.5 \mathrm{ml}$ of $0.02 \mathrm{~N}$ aqueous $\mathrm{HCl}$, and then $20 \mu \mathrm{l}$ of them were separately applied to HITACHI L-8500A Amino Acid Analyzer.

(b) Absolute configuration of the $\alpha$-amino acids

The approximately $1 \mathrm{mg}$ of each compound was hydrolyzed with $6 \mathrm{~N} \mathrm{HCl}$ for 24 hours. The hydrolysate was concentrated and dissolved in water $(0.5 \mathrm{ml})$, and then $20 \mu \mathrm{l}$ of the resulting solution was applied to the chiral HPLC analysis. The chiral HPLC analysis was carried out with the following general conditions: column; OA-5000 (Sumika Chemical Analysis Service, Ltd.), flow rate; $1.0 \mathrm{ml} / \mathrm{minute}$, detection; UV $254 \mathrm{~nm}$, temperature; ambient temperature.

The HPLC analysis for Ile and Leu was carried out with MeOH - $3 \mathrm{~mm} \mathrm{CuSO}_{4}$ 15:85 (v/v). For this HPLC analysis, D-Ile and L-Ile were eluted at 15.2 minutes and 11.8 minutes and D-Leu and L-Leu were eluted at 19.7 minutes and 13.3 minutes, respectively.

The HPLC analysis for Val was carried out with $1 \mathrm{~mm}$ $\mathrm{CuSO}_{4}$. For this HPLC analysis, D-Val and L-Val were eluted at 21.1 minutes and 12.3 minutes, respectively.

The HPLC analysis for $\beta$-Phe was carried out with MeOH - $3 \mathrm{mM} \mathrm{CuSO}_{4} 8: 92(\mathrm{v} / \mathrm{v})$. For this HPLC analysis, $\mathrm{D}-\beta$-Phe and $\mathrm{L}-\beta$-Phe were eluted at 26.9 minutes and 23.8 minutes, respectively.
Protein Sequence Analysis (Edman Degradation Method)

The $c a .1 \mathrm{mg}$ of each compound was dissolved in $10 \mathrm{ml}$ of $0.1 \%$ TFA and then $20 \mu 1$ of the solution was analyzed on a Protein Sequencer 473A (Applied Biosystems).

\section{Preparation of 7 and 8 from 4}

(i) A solution of $4(5.0 \mathrm{~g}, 14.6 \mathrm{mmol})$ in $6 \mathrm{~N} \mathrm{HCl}(500 \mathrm{ml})$ was kept at $37^{\circ} \mathrm{C}$ for 4 days. The reaction mixture was cooled with an ice bath, and $10 \mathrm{~N} \mathrm{NaOH}$ was cautiously added to attain $\mathrm{pH} 5$. The adjusted solution was passed through a column of SP-207 $(250 \mathrm{ml})$ and the column was successively washed with water $(750 \mathrm{ml})$. The effluent was applied to a column of activated charcoal $\mathrm{LH}_{2} \mathrm{C}(200 \mathrm{ml}$, Takeda Chemical Industries). After washing with water $(600 \mathrm{ml})$, the column was eluted with $10 \%$ aqueous $2-\mathrm{PrOH}$ $(600 \mathrm{ml})$. The eluate was concentrated to give $1.87 \mathrm{~g}$ of crude gum. The gum was then crystallized in $3 \mathrm{ml}$ of $\mathrm{EtOH}-\mathrm{H}_{2} \mathrm{O}(2: 1)$ to give colorless prisms of $8(412 \mathrm{mg}$, $16 \%$ yield); ${ }^{1} \mathrm{H}$ NMR $\delta 3.26(1 \mathrm{H}, \mathrm{m}), 3.44(2 \mathrm{H}, \mathrm{m}), 3.54$ $(1 \mathrm{H}$, ddd $J=2.2,4.8,9.5 \mathrm{~Hz}), 3.83(1 \mathrm{H}, \mathrm{dd}, J=4.6,9.5 \mathrm{~Hz})$, $3.87(1 \mathrm{H}, \mathrm{br}), 4.68(1 \mathrm{H}, \mathrm{t}, J=5.8), 4.92(1 \mathrm{H}, \mathrm{d}, J=4.3)$, $5.03(1 \mathrm{H}, \mathrm{d}, J=4.6), 5.05(1 \mathrm{H}, \mathrm{d}, J=4.8), 7.00(1 \mathrm{H}, \mathrm{s})$; IR; $v_{\max }(\mathrm{KBr}) \mathrm{cm}^{-1} 3317,1633,1421,1338,1103$; FAB-MS $m / z 178[\mathrm{M}+\mathrm{H}]^{+}$.

(ii) The mother liquid of $\mathbf{8}$ was concentrated and chromatographed on a column of Sephadex G-10 (550 ml) eluting with water. Fractions containing 7 were concentrated and lyophilized to give $638 \mathrm{mg}$ of a crude powder, and then crystallized from $\mathrm{EtOH}-\mathrm{H}_{2} \mathrm{O}(2: 1)$ to give colorless needles of 7 (505 mg, 18\% yield); ${ }^{1} \mathrm{H}$ NMR $\delta$ $3.36(1 \mathrm{H}$, br $), 3.56(2 \mathrm{H}, \mathrm{d}, J=6.8 \mathrm{~Hz}), 3.70(1 \mathrm{H}, \mathrm{d}$, $J=9.4 \mathrm{~Hz}), 3.83(1 \mathrm{H}, \mathrm{d}, J=9.4 \mathrm{~Hz}), 4.27(1 \mathrm{H}, \mathrm{s}), 7.62(3 \mathrm{H}$, br s); IR; $\nu_{\max }(\mathrm{KBr}) \mathrm{cm}^{-1} 3421,1589,1419,1358,1066$; FAB-MS $m / z 196[\mathrm{M}+\mathrm{H}]^{+}$.

\section{Crystal Analysis of $\mathbf{8}$}

Colorless prism crystals obtained from EtOH $-\mathrm{H}_{2} \mathrm{O}$ solution were subjected to X-ray crystal analyses. Appropriately sized crystals were cut into cubes and were gently shaken in an aliquot of $50 \%$ ethanol aqueous solution to obtain sphere like crystals. Intensity data were collected for all the reflections in the reciprocal space within a resolution limit by a four-circle diffractometer, RIGAKU AFC5R, using $\mathrm{Cu}-\mathrm{K} \alpha$ radiation. Spherical absorption correction was applied. The structure was solved by direct methods (SIR92 ${ }^{14)}$ in teXsan ${ }^{15)}$ software package) and refined by SHELX-97 ${ }^{16)}$.

\section{Preparation of 9 from 7}

To a solution of $7(280 \mathrm{mg}, 1.44 \mathrm{mmol})$ in $0.3 \mathrm{M}$ aqueous 
$\mathrm{KHCO}_{3}(28 \mathrm{ml})$, carbobenzoxy chloride $(432 \mu 1,2.88 \mathrm{mmol})$ was added and the mixture was stirred at room temperature for 3.5 hours while cautiously adding $0.3 \mathrm{M}$. aqueous $\mathrm{KHCO}_{3}$ to maintain $\mathrm{pH}$ above 8 . The mixture was adjusted to $\mathrm{pH} 7$ and then washed twice with EtOAc. The aqueous layer was applied to a column of HP-20S $(50 \mathrm{ml})$ and eluted with $5 \sim 30 \%$ aqueous $2-\mathrm{PrOH}(150 \mathrm{ml})$. The eluate was concentrated and lyophilized to give crude powder of 5-benzyloxycarbonylamino-2,3,4,6-tetrahydroxyhexanoic acid (404 mg, 86\%).

The obtained compound (390 $\mathrm{mg}, 1.18 \mathrm{mmol}$ ) was dissolved in abs. pyridine $(5 \mathrm{ml})$, and acetic anhydride $(5 \mathrm{ml})$ was added gradually to the solution. After being stirred for 20 hours at room temperature, the reaction mixture was concentrated to give an oily residue $(530 \mathrm{mg})$. To a solution of the residue in acetone $(20 \mathrm{ml})$, acetic anhydride $(240 \mu \mathrm{l})$ and TFA $(240 \mu \mathrm{l})$ were added and the mixture was stirred for 2 hours at room temperature. The reaction mixture was concentrated, poured into $\mathrm{H}_{2} \mathrm{O}$ and extracted with EtOAc. The organic layer was washed with $3 \%$ aqueous $\mathrm{NaHCO}_{3}$, saturated aqueous $\mathrm{NaCl}$, dried over $\mathrm{Na}_{2} \mathrm{SO}_{4}$, and evaporated to dryness. The residue (554 mg) was purified by preparative HPLC (column: YMC-Pack ODS SH-363-15, i.d. $30 \times 250 \mathrm{~mm})$ using $\mathrm{CH}_{3} \mathrm{CN}: 50 \mathrm{~mm}$ $\mathrm{H}_{3} \mathrm{PO}_{4}-\mathrm{KH}_{2} \mathrm{PO}_{4}(\mathrm{pH} 3.0)(40: 60)$. Fractions containing 9 were combined, concentrated and then extracted with EtOAc. The extract was washed with saturated aqueous $\mathrm{NaCl}$, dried over $\mathrm{Na}_{2} \mathrm{SO}_{4}$ and concentrated to give 9 (259 mg, 49\%); 'H NMR $\delta 2.04(3 \mathrm{H}, \mathrm{s}), 2.11(3 \mathrm{H}, \mathrm{s}), 2.14$ $(3 \mathrm{H}, \mathrm{s}), 4.14(1 \mathrm{H}, \mathrm{dd}, J=5.8,10.8 \mathrm{~Hz}), 4.34(2 \mathrm{H}, \mathrm{m}), 5.10$ $(1 \mathrm{H}, \mathrm{d}, J=10.8 \mathrm{~Hz}), 5.13(2 \mathrm{H}, \mathrm{m}), 5.50(1 \mathrm{H}$, br s$), 5.51$ $(1 \mathrm{H}, \mathrm{d}, J=5.3), 7.3 \sim 7.4(5 \mathrm{H}, \mathrm{m}) . \mathrm{IR} ; v_{\max }(\mathrm{KBr}) \mathrm{cm}^{-1}$ $3399,1778,1722,1535,1227,1108$. FAB-MS $m / z 438$ $[\mathrm{M}+\mathrm{H}]^{+}$.

\section{Preparation of 10 from 9}

Compound 9 (258 $\mathrm{mg}, 0.59 \mathrm{mmol})$ was dissolved in MeOH $(15 \mathrm{ml})$, and pyridine $(50 \mu 1,0.62 \mathrm{mmol})$ was added to the solution. After being stirred at room temperature for 26 hours, the reaction mixture was concentrated, poured into water and then extracted with EtOAc. The organic layer was washed with water, dried over $\mathrm{Na}_{2} \mathrm{SO}_{4}$ and concentrated to afford $10(259 \mathrm{mg}, 94 \%) ;{ }^{1} \mathrm{H}$ NMR $\delta 2.06$ $(3 \mathrm{H}, \mathrm{s}), 2.08(3 \mathrm{H}, \mathrm{s}), 2.20(3 \mathrm{H}, \mathrm{s}), 3.73(3 \mathrm{H}, \mathrm{s}), 3.85(1 \mathrm{H}, \mathrm{d}$, $J=9.6), 4.08(2 \mathrm{H}, \mathrm{m}), 4.31(1 \mathrm{H}, \mathrm{dd}, J=7.2,10.7 \mathrm{~Hz}), 5.04$ $(1 \mathrm{H}, \mathrm{d}, J=12.2), 5.12(1 \mathrm{H}$, br s), $5.13(1 \mathrm{H}, \mathrm{d}, J=12.2), 5.30$ $(1 \mathrm{H}, \mathrm{d}, J=9.6), 5.41(1 \mathrm{H}, \mathrm{d}, J=1.8), 7.3 \sim 7.4(5 \mathrm{H}, \mathrm{m})$. IR; $v_{\max }(\mathrm{KBr}) \mathrm{cm}^{-1} 3437,1751,1527,1228,1055$. FAB-MS $m / z 470[\mathrm{M}+\mathrm{H}]^{+}$.

\section{Preparation of 11a and $11 \mathbf{b}$ from 10}

(i) To a solution of $10(10 \mathrm{mg}, 0.0213 \mathrm{mmol})$ in pyridine $(0.5 \mathrm{ml}), \quad(-)$ - $\alpha$-methoxy- $\alpha$-trifluoromethylphenylacetyl chloride $(100 \mathrm{mg}, 0.40 \mathrm{mmol})$ and dimethylaminopyridine $(10 \mathrm{mg})$ were added and the mixture was stirred at room temperature for 100 hours. The reaction mixture was concentrated, poured into water and then extracted with EtOAc. The extract was washed with $0.1 \mathrm{~N}$ aqueous $\mathrm{HCl}$, $3 \%$ aqueous $\mathrm{NaHCO}_{3}$ and water. The organic layer was dried over $\mathrm{Na}_{2} \mathrm{SO}_{4}$, concentrated and purified by preparative HPLC (column: YMC-Pack ODS D-ODS-5, i.d. $30 \times 250 \mathrm{~mm})$ using $\mathrm{CH}_{3} \mathrm{CN}: 20 \mathrm{~mm} \mathrm{KH}_{2} \mathrm{PO}_{4}(\mathrm{pH} 4.5)$ $(40: 60 \sim 60: 40)$. Fractions containing 11a were combined, concentrated and then extracted with EtOAc. The organic layer was washed with water, dried over $\mathrm{Na}_{2} \mathrm{SO}_{4}$ and concentrated to give $11 \mathrm{a}$ ( $5.6 \mathrm{mg}, 38 \%$ yield); ${ }^{1} \mathrm{H}$ NMR $\left(5.6 \mathrm{mg} / 0.5 \mathrm{ml}, \mathrm{CDCl}_{3}\right) \delta 3.454(3 \mathrm{H}, \mathrm{s}), 3.690(3 \mathrm{H}, \mathrm{s})$, $3.887(2 \mathrm{H}, \mathrm{dd}, J=1.5,7.3 \mathrm{~Hz}), 4.440(1 \mathrm{H}, \mathrm{m}), 4.595(1 \mathrm{H}, \mathrm{d}$; $J=10.4 \mathrm{~Hz}), 4.785(1 \mathrm{H}, \mathrm{d}, J=1.6 \mathrm{~Hz}), 4.984(1 \mathrm{H}, \mathrm{d}$, $J=12.1 \mathrm{~Hz}), 5.130(1 \mathrm{H}, \mathrm{d}, J=12.1 \mathrm{~Hz}), 5.444(1 \mathrm{H}, \mathrm{dd}$, $J=1.6,9.3 \mathrm{~Hz}), 5.634(1 \mathrm{H}, \mathrm{dd}, J=1.7,9.3 \mathrm{~Hz}), 7.32 \sim 7.39$ $(5 \mathrm{H}, \mathrm{m}), 7.43 \sim 7.50(5 \mathrm{H}, \mathrm{m}) .{ }^{13} \mathrm{C}$ NMR $\delta 20.33(\mathrm{q}, 3-$ $\left.\mathrm{OCOCH}_{3}\right), 20.47\left(\mathrm{q}, 2-\mathrm{OCOCH}_{3}\right), 20.53\left(\mathrm{q}, 6-\mathrm{OCOCH}_{3}\right.$ ), 48.99 (d, C-5), 52.79 (q, $\left.\mathrm{COOCH}_{3}\right), 55.26$ (q), 62.52 (t, C6), $67.72(\mathrm{~d}, \mathrm{C}-3), 69.55$ (d, C-2), 70.63 (d, C-4), 127.35 (d), 128.30 (d), 128.38 (d), 128.59 (s), 128.82 (d), 129.04 (d), 130.18 (s), 130.67 (s), 130.89 (s), 135.90 (s), 155.82 (s), $165.32(\mathrm{~s}), 167.24(\mathrm{~s}, \mathrm{C}-1), 169.12\left(\mathrm{~s}, 3-\mathrm{OCOCH}_{3}\right)$, $169.84\left(\mathrm{~s}, 2-\mathrm{OCOCH}_{3}\right), 170.37\left(\mathrm{~s}, 6-\mathrm{OCOCH}_{3}\right)$.

(ii) Compound $11 \mathrm{~b}$ was obtained from $10(10 \mathrm{mg})$ and (+)- $\alpha$-methoxy- $\alpha$-trifluoromethylphenylacetyl chloride (100 $\mathrm{mg}, 0.40 \mathrm{mmol})$ in a manner similar to that described for the synthesis of 11 a (14.4 mg, 98\% yield); ${ }^{1} \mathrm{H}$ NMR $\left(14.4 \mathrm{mg} / 1.2 \mathrm{ml}, \mathrm{CDCl}_{3}\right) \delta 3.489(3 \mathrm{H}, \mathrm{s}), 3.695(3 \mathrm{H}, \mathrm{s})$, $3.837(2 \mathrm{H}, \mathrm{d}, J=7.3 \mathrm{~Hz}), 4.432(1 \mathrm{H}, \mathrm{m}), 4.636(1 \mathrm{H}, \mathrm{d}$, $J=10.6 \mathrm{~Hz}), 4.801 \quad(1 \mathrm{H}, \mathrm{d}, J=1.6 \mathrm{~Hz}), 4.975(1 \mathrm{H}, \mathrm{d}$, $J=12.1 \mathrm{~Hz}), 5.119(1 \mathrm{H}, \mathrm{d}, J=12.1 \mathrm{~Hz}), 5.447(1 \mathrm{H}, \mathrm{dd}$, $J=1.6,9.0 \mathrm{~Hz}), 5.658(1 \mathrm{H}, \mathrm{dd}, J=1.6,9.0 \mathrm{~Hz}), 7.32 \sim 7.38$ $(5 \mathrm{H}, \mathrm{m}), 7.43 \sim 7.52(5 \mathrm{H}, \mathrm{m}) .{ }^{13} \mathrm{C} \mathrm{NMR} \delta 20.32(\mathrm{q}, 3-$ $\left.\mathrm{OCOCH}_{3}\right), 20.45\left(\mathrm{q}, 2-\mathrm{OCOCH}_{3}\right), 20.54$ (q, 6-OCOCH$)_{3}$, 48.95 (d, C-5), 52.81 (q, $\left.\mathrm{COOCH}_{3}\right), 55.39$ (q), 62.48 (t, C6), $67.90(\mathrm{~d}, \mathrm{C}-3), 69.62(\mathrm{~d}, \mathrm{C}-2), 70.66(\mathrm{~d}, \mathrm{C}-4), 127.21$ (d), 128.33 (d), 128.38 (d), 128.58 (s), 128.81 (d), 129.04 (d), $130.21(\mathrm{~s}), 130.71$ (s), $130.92(\mathrm{~s}), 135.86(\mathrm{~s}), 155.82$ (s), $165.36(\mathrm{~s}), 167.19(\mathrm{~s}, \mathrm{C}-1), 169.15\left(\mathrm{~s}, 3-\mathrm{OCOCH}_{3}\right)$, $169.92\left(\mathrm{~s}, 2-\mathrm{OCOCH}_{3}\right), 170.37\left(\mathrm{~s}, 6-\mathrm{OCOCH}_{3}\right)$.

\section{Preparation of 13 from 3}

To a solution of $3(50 \mathrm{mg}, 0.11 \mathrm{mmol})$ in aqueous $0.05 \mathrm{M}$ $\mathrm{KHCO}_{3}(20 \mathrm{ml}), \mathrm{Ac}_{2} \mathrm{O}(22 \mu 1,0.23 \mathrm{mmol})$ was added and 
the mixture was stirred at room temperature for an hour while cautiously adding aqueous $1 \mathrm{M} \mathrm{KHCO}_{3}$ to maintain $\mathrm{pH}$ above 8 . To the reaction mixture, $1 \mathrm{~N}$ aqueous $\mathrm{HCl}$ was added to attain $\mathrm{pH}$ 6.5. The resulting solution was applied to a column of HP-20 (5ml) and washed with water $(15 \mathrm{ml})$. Compound 13 was eluted with $30 \%$ aqueous 2$\mathrm{PrOH}(40 \mathrm{ml})$ and the eluate was concentrated and freezedried to give a powder of $13(49 \mathrm{mg}, 90 \%)$ as potassium salt; 'H NMR $\delta 0.84(3 \mathrm{H}, \mathrm{d}, J=6.4 \mathrm{~Hz}), 0.87(3 \mathrm{H}, \mathrm{d}$, $J=6.5 \mathrm{~Hz}), 1.44(2 \mathrm{H}, \mathrm{br}), 1.57(1 \mathrm{H}, \mathrm{m}), 1.83(3 \mathrm{H}, \mathrm{s}), 2.53$ $(2 \mathrm{H}, \mathrm{m}), 3.45(2 \mathrm{H}, \mathrm{m}), 3.48(1 \mathrm{H}, \mathrm{d}, J=9.8 \mathrm{~Hz}), 3.76(1 \mathrm{H}, \mathrm{d}$, $J=9.8 \mathrm{~Hz}), 3.95(1 \mathrm{H}, \mathrm{m}), 4.12(1 \mathrm{H}, \mathrm{br} \mathrm{s}), 4.30$ (1H, q like), $5.11(1 \mathrm{H}, \mathrm{m}), 7.16(1 \mathrm{H}, \mathrm{m}), 7.23(2 \mathrm{H}, \mathrm{m}), 7.32(1 \mathrm{H}, \mathrm{d}$, $J=7.0 \mathrm{~Hz}), 7.33(2 \mathrm{H}, \mathrm{m}), 8.05(1 \mathrm{H}, \mathrm{d}, J=8.3 \mathrm{~Hz}), 8.75(1 \mathrm{H}$, d, $J=7.7 \mathrm{~Hz}, \mathrm{NH})$; FAB-MS $m / z 498[\mathrm{M}+\mathrm{H}]^{+}$; HPLC, $\mathrm{Rt}=15.5$ minutes. Solvent system: $\mathrm{CH}_{3} \mathrm{CN}-20 \mathrm{~mm}$ $\mathrm{KH}_{2} \mathrm{PO}_{4} 15: 85(\mathrm{v} / \mathrm{v})$

\section{Preparation of $\mathbf{1 4}$ from 3}

To a solution of $3(50 \mathrm{mg}, 0.11 \mathrm{mmol})$ in $\mathrm{MeOH}(10 \mathrm{ml})$, $10 \% \mathrm{HCl}-\mathrm{MeOH}(10 \mathrm{ml}$, Tokyo Chemical Industries Co., Ltd.) was added and the mixture was stirred at room temperature for 16 hours. The reaction mixture was concentrated, poured into water $(10 \mathrm{ml})$ and adjusted to $\mathrm{pH}$ 6.5 with aqueous $1 \mathrm{M} \mathrm{KHCO}_{3}$. The resulting solution was subjected to a column of HP-20 $(10 \mathrm{ml})$. After washing with water $(30 \mathrm{ml})$, the column was eluted with $30 \%$ aqueous 2-PrOH $(30 \mathrm{ml})$ and $50 \%$ aqueous 2-PrOH $(30 \mathrm{ml})$. Fractions containing 14 were combined, concentrated and lyophilized to give a powder of $14(34 \mathrm{mg}, 66 \%)$ as hydrochloride salt; ${ }^{1} \mathrm{H}$ NMR $\delta 0.86(3 \mathrm{H}, \mathrm{d}, J=6.6 \mathrm{~Hz}), 0.89$ $(3 \mathrm{H}, \mathrm{d}, J=6.7 \mathrm{~Hz}), 1.24(1 \mathrm{H}, \mathrm{ddd}, J=4.8,9.2,13.5 \mathrm{~Hz})$, $1.46(1 \mathrm{H}$, ddd, $J=4.4,9.0,13.5 \mathrm{~Hz}), 1.75(1 \mathrm{H}, \mathrm{m}), 2.84$ $(1 \mathrm{H}, \mathrm{dd}, J=7.4,15.8 \mathrm{~Hz}), 2.91(1 \mathrm{H}, \mathrm{dd}, J=6.8,15.8 \mathrm{~Hz})$, $3.40 \sim 3.48(3 \mathrm{H}, \mathrm{m}), 3.51(3 \mathrm{H}, \mathrm{s}), 3.76(1 \mathrm{H}, \mathrm{br}), 3.97(1 \mathrm{H}$, br), $4.11(1 \mathrm{H}$, br d, $J=4.3 \mathrm{~Hz}), 4.56(1 \mathrm{H}, \mathrm{d}, J=6.3 \mathrm{~Hz}), 4.63$ $(1 \mathrm{H}$, br s), $4.90(1 \mathrm{H}$, br d, $J=6.0 \mathrm{~Hz}), 5.24(1 \mathrm{H}$, br d, $J=7.0 \mathrm{~Hz}), 5.27(1 \mathrm{H}, \mathrm{m}), 7.20 \sim 7.37(5 \mathrm{H}, \mathrm{m}), 7.78(1 \mathrm{H}, \mathrm{d}$, $J=7.8 \mathrm{~Hz}), 8.12(1 \mathrm{H}, \mathrm{d}, J=8.9 \mathrm{~Hz}) ;$ FAB-MS $m / z 470$ $[\mathrm{M}+\mathrm{H}]^{+} ; \quad \mathrm{HPLC} ; \mathrm{Rt}=9.4$ minutes. Solvent system: $\mathrm{CH}_{3} \mathrm{CN}-20 \mathrm{mM} \mathrm{KH}_{2} \mathrm{PO}_{4}-\mathrm{H}_{3} \mathrm{PO}_{4}(\mathrm{pH} 3.0) 20: 80(\mathrm{v} / \mathrm{v})$.

\section{Acknowledgments}

We are grateful to Mr. K. HAYASH for the NMR experiments and Mrs. K. HigashiKaWA for the X-ray analyses. Thanks are due to the members of the large-scale production. We also thank Messrs. M. MAKI and H. HAMAGUCH for their skillful technical assistance.

\section{Reference}

1) Warren, J. R. \& B. J. Marshall: Unidentified curved bacilli on gastric epithelium in active chronic gastritis. Lancet i: $1273 \sim 1275,1983$

2) Graham, D. Y.; G. M. Lew \& P. D. KLeIN: Effect of treatment of Helicobacter pylori infection on the longterm recurrence of gastric or duodenal ulcer; A randomized, controlled study. Ann. Intern. Med. 116: 705 708, 1992

3) NIH consensus: Helicobacter pylori in peptic disease. JAMA 272: 65 69, 1994

4) The Maastricht consensus report: Current European concepts in the management of Helicobacter pylori infection. Gut 41: 8 13, 1997

5) Unge, P. \& A. Brestad: Pooled analysis of antiHelicobacter pylori treatment regimens. Scand. J. Gastroenterol 31 (Suppl. 220): 27 40, 1996

6) Nakao, M.; K. Miyagawa, Y. Nakano, T. Sakane, M. TADA, O. Nishimura \& M. FuJINo: Pyloricidins, novel anti-Helicobacter pylori antibiotics produced by Bacillus sp. I. Taxonomy, fermentation and biological activity. J. Antibiotics 54: 926 933, 2001

7) Cohen, S. G. \& S. Y. Weinstein: Hydrolysis of D( -$)$ ethyl $\beta$-phenyl- $\beta$-hydroxypropionate and $\mathrm{D}(-)$-ethyl $\beta$ phenyl- $\beta$-acetamidopropionate by $\alpha$-chymotrypsin. J. Am. Chem. Soc. 86: 725 728, 1964

8) FLACK, H. D.: On enantiomorph-polarity estimation. Acta Cryst. A39: 876 881, 1983

9) Ohtani, I.; T. Kusumi, Y. Koshman \& H. Kakisawa: High-field FT NMR application of Mosher's method. The absolute configuration of marine terpenoids. J. Am. Chem. Soc. 113: 4092 4096, 1991

10) DekKer, K. A.; T. Nagaki, T. D. Gootz, L. H. Huang, Y. Kojima, W. E. Kohlbrenner, Y. Matsunaga, P. R. McGuirk, E. Nomura, T. SAKakibara, S. Sakemi, Y. Suzuki, Y. Yamauchi, N. Yoshikawa \& N. KoJima: New quilonone compounds from Pseudonocardia sp. with selective and potent anti-Helicobacter pylori activity: Taxonomy of producing strain, fermentation, isolation, structural elucidation and biological activities. J. Antibiotics 51: 145 152, 1998

11) TanaKa, K.; M. Watanabe, Y. Takeda, K. Koyama \& K. WASHIZAKI (Yamanouchi Pharmaceutical Co., Ltd., Japan): Anti-Helicobacter pylori agents containing 2-(2heptenyl)-3-methyl-4(1H)quinolone. JPK 10-279561, October, 20, 1998

12) ChibA, N.; M. Kanda, J. Takashima \& T. Mikawa (Mitsubishi Chemical Industries Ltd., Japan): Brefeldin A for the treatment of Helicobacter pylori infections. JPK 9-157168, June 17, 1997

13) Dekker, K. A.; T. Nagaki, T. D. Gootz, K. Kaneda, E. Nomura, T. Sakakibara, S. Sakemi, Y. Sugie, Y. YamauchI, N. YoshIKaWA \& N. KoJIMA: CJ-12,954 and its congeners, new anti-Helicobacter pylori compounds produced by Phanerochaete velutina: Fermentation, isolation, structural elucidation and biological activities. J. Antibiotics 50: 833 839, 1997

14) Altomare, A.; G. Cascarano, C. Giacovazzo, A. Guagliardi, M. C. Burla, G. Polidori \& M. Camalli: SIR92 - a program for automatic solution of crystal structures by direct methods. J. Appl. Cryst. 27: 435, 1994 
15) teXsan. Single crystal structure analysis software, version $1.10 \mathrm{~b}$. Molecular Structure Corporation, The Woodlands, TX. 77381. USA, 1999
16) SHELdRICK, G. M: SHELX-97. Program for the refinement of crystal structures. University of Göttingen, Germany, 1997 